artigo

[ PEDRO RENAN DE OLIVEIRA ]

Bacharel em Economia Doméstica (Universidade Federal do Ceará - UFC), graduando em Design-Moda (UFC), Estudos sobre Cultura, Arte e Luxo (EAC, Paris), bolsista no

Programa de Educação Tutorial (UFC).

E-mail: pedro.oliveiras@outlook.com

[ FRANCISCA RAIMUNDA NOGUEIRA MENDES ]

Graduada em História. Mestre e Doutora em Sociologia. Professora de História da

Moda na UFC, onde pesquisa e orienta trabalhos sobre Moda, Cultura, Artesanato,

Consumo e História.

E-mail: franciscarnmendes@gmail.com

\title{
A hora do Brasil: novas percepções sobre 0 consumo e a ressignificação do artesanato do Ceará
}

The time of Brazil: new perceptions about consumption and the resignification of Ceará handicraft

[resumo] 0 mundo globalizado pressupõe a produção massificada. Na contramão desse sistema, existe uma tendência à valorização de técnicas manuais na confecção de objetos. Novas ações na área do design ${ }^{1}$ e da moda são estimuladas, visando à produção de bens com identidade cultural e com aspectos atrativos ao mercado. Esse foi o caso do projeto A hora do Brasil, realizado no ano de 2012 em Fortaleza, que buscou a ressignificação do artesanato por meio da união de profissionais e artesãos locais. Com a análise da coleção produzida, bem como do catálogo e de vídeos e matérias em sites especializados, busca-se entender como o artesanato pode ser, hoje, objeto de desejo, além de elemento de diferenciação em meio à cultura de consumo de massa.

\section{palavras-chave}

\section{artesanato; globalização; design; consumo.}

[abstract] The globalized world presumes a massificated production. Against this system, there is a trend about the valorization of manual techniques in the making of objects. New actions in the field of design and fashion are encouraged, aiming the production of goods with a cultural identity and attractive features to the market. This was the case of the project The Time of Brazil, held in 2012 in Fortaleza, that sought to resignify the handicrafts by means of the union of professionals and local artisans. Through the analysis of the collection produced, as well as the catalog, videos and materials on specialized sites, we seek to understand how this crafts can be an object of desire in contemporary times, being a differentiating element in the mass consuming culture.

[keywords] crafts; globalization; design; consumption. 


\section{Introdução}

As relações estabelecidas entre as produções global e local apresentam-nos uma discussão sobre a valorização dos saberes populares e a importância da manutenção de nossas heranças. Vemos, cada vez mais em voga, um discurso que versa sobre a regionalização dos produtos, sejam eles de moda, design, gastronômicos etc. Tem-se em mente, diante da produção massificada, que produtos regionais são dotados de saberes específicos, de tradições culturais que lhes agregam valor, tornando-os únicos.

Diante do exposto, este trabalho objetiva identificar os parâmentros de relação entre os temas citados, buscando estratégias para a produção e a valorização de bens com apelo regional, com foco no artesanato produzido no estado do Ceará. Para tanto, lança-se mão, como objeto de estudo, do reality project $A$ Hora do Brasil, ação desenvolvida pelo Serviço Nacional de Aprendizagem Comercial (Senac/CE) em parceria com o Dragão Fashion Brasil (DFB), semana de moda que acontece anualmente na cidade de Fortaleza e que teve direção criativa do designer Jum Nakao no ano de 2012. A escolha do objeto de estudo deu-se por causa da participação de um dos autores no referido projeto, despertando seu interesse por trabalhos relacionados à cultura local.

Para a realização da pesquisa, foi feita uma revisão de literatura sobre o tema escolhido, trabalhando-se com análises do que já foi escrito até então. 0 estudo supracitado foi importante para a formação de um arcabouço teórico que guiou a continuidade da pesquisa. Posteriormente, foi feito o estudo do material produzido no reality project. Essa fase objetivou identificar os parâmetros de relação entre 0 artesanato e o design na contemporaneidade. Para essa análise, foi utilizada a coleção desenvolvida no projeto, focando os produtos e processos utilizados na construção do desfile, bem como o catálogo e o minidocumentário, produzidos também pelo Senac/ $\mathrm{CE}$, e matérias divulgadas em sites especializados em moda.

Esse estudo mostrou que a união entre o artesanato e o design se estabelece como estratégia para a construção de um produto com identidade, valores culturais agregados e elementos que podem ser diferenciadores diante de uma economia globalizada, aspectos esses detalhados ao longo do trabalho que se segue.

\section{Do global ao local: novas percepções da produção e do consumo}

A globalização é um processo que se desenvolveu com o crescimento e a expansão do capitalismo, sistema econômico que está diretamente ligado à rede de produção e de troca de produtos entre diversos países do mundo. Com o advento das inovações tecnológicas e científicas, notadamente aquelas ligadas à comunicação, houve um aumento desse fenômeno, estabelecendo relações mais rápidas de produção, consumo e troca de bens e serviços, de acordo com Santos (2001).

Para Avelar (2011), esse fato, tratado tanto em termos econômicos como culturais, é caracterizado por um percurso de trocas entre culturas e locais distintos, o que envolve mercadorias e pessoas.

Bauman (1999) destaca o processo de globalização como algo irremediável e irreversível pelo qual todos são afetados, sendo encarado positivamente por uns e negativamente por outros. 0 autor distingue o ser global, em movimento com o seu tempo e espaço, como parte integrante desse sistema; e o ser local, caracterizado pela privação das influências de um mundo conectado, estando periférico a esse último.

0 mundo globalizado pressupõe, ainda de acordo com o autor supracitado, a produção de desejos efêmeros, na medida em que os consumidores estão em movimento constante e essa ação é acompanhada por necessidades instantâneas, típicas de uma sociedade de consumo.

A produção just-in-time é um bom exemplo desse fenômeno, pois ocorre de forma desterritorializada, pulverizada, com inúmeras localidades participantes em um mesmo processo, tendo como consequência a desvalorização da força trabalhadora. Isso se dá porque o capital transita instantaneamente por todo o globo e não depende dos locais onde a força de trabalho está concentrada, isto é, os lugares de produção estão dispersos por todo o mundo. (AVELAR, 2011, p. 83) 
Ortiz (1994) apud Avelar (2011) colabora com a discussão, definindo globalização como um sistema de produção, distribuição e consumo de produtos (bens e serviços) diante de uma economia mundializada, acontecendo de forma desterritorializada, visto que esse modo produtivo não está mais centrado em um único local, mas distribuído pelo mundo. Pode-se dizer o mesmo sobre a cultura, que se caracteriza, cada vez mais, por uma hibridação de diversas manifestações, proporcionadas pelos avanços na área da comunicação.

A produção e a aquisição em abundância de bens acarretam, de acordo com Baudrillard (2008), uma série de consequências, tais como a poluição do ar e da água, a destruição de lugares e paisagens, além de prejuízos culturais e pressões psicológicas e sociais enfrentadas pelos indivíduos que fazem parte do sistema. Bauman (2013) trata da economia líquida-moderna, na qual a orientação é destinada apenas ao consumo, quando se oferecem produtos em excesso, pensando-se sempre no seu rápido envelhecimento, a fim de que sejam logo substituídos por outros, que prometem ser melhores que seus precedentes.

Sudjic (2010), analisando o design e seus arquétipos na atualidade, corrobora com essa análise, enfatizando o alto grau de consumo existente nos dias atuais. Consumo esse caracterizado por trocas desenfreadas de produtos, mesmo quando não se há motivos aparentes para suas substituições. Segundo o autor, esse fenômeno é caracterizado por alguns fatores, tais como a pressão social incessante por adquirir dinheiro e a publicidade intensiva de bens que se modificam a cada dia.

Nesse contexto, podemos estabelecer um paralelo entre o processo de globalização e seus efeitos negativos sobre as culturas e tradições populares. De acordo com França (2005), a globalização trouxe consigo, além de suas transformações políticas e econômicas, a degradação dos conhecimentos locais, resultando em produções homogêneas e pasteurizadas - muitas vezes mal executadas, sem identidade e raízes -, voltadas somente para agradar ao mercado de consumo.

Lipovetsky (2007) analisa a evolução do consumo em nossa sociedade, delimitando fases definidas por acontecimentos que são contemporâneos (e consequências) da evolução da globalização. A primeira delas, ocorrida entre 1880 e a Segunda Guerra Mundial, foi marcada pela evolução dos transportes e da comunicação, que irá proporcionar maior regularidade no processo produtivo e mais velocidade na distribuição. É desse período também o aparecimento das marcas e da publicidade, até então rudimentares, que vão revolucionar o ato de compra. Surgem os grandes magazines que oferecem múltiplas opções e uma democratização do acesso dos objetos.

A segunda fase descrita pelo autor inicia-se nos anos 1950, orientada pelo regimento fordista de produção, favorecendo rapidez e padronização na fabricação de bens de consumo. Esses fatores vão proporcionar uma prática de distribuição de massa, quando se desenvolvem os grandes supermercados, nos quais são oferecidos produtos variados, renovados constantemente para seduzir uma clientela ávida por novidades.

A terceira fase, que surge no final da década de 1970 e nos é contemporânea, é marcada por um repensar das nossas formas de consumo. Surgem os hiperconsumidores: o consumo passa a ser um ato individual e ligado às emoções do comprador. Em meio à multiplicidade de ofertas, e tendo em vista os efeitos negativos da produção massificada, o indivíduo passa a buscar produtos relacionados ao seu estilo de vida e que não agridam o meio ambiente. Esse terceiro periodo é apresentado de forma mais detalhada nas próximas seções.

\section{A evolução da globalização e seus efeitos para os produtos locais}

Porto Alegre (1994) analisa a evolução das artes e dos ofícios ao longo da história e discute a forma como a Revolução Industrial e, consequentemente a globalização, veio acentuar e distanciar os produtos feitos de forma manual daqueles executados pelas máquinas, o que pode ser evidenciado na seguinte passagem:

À medida que as mãos eram substituídas pelas máquinas, os mestres de ofícios sofriam nova diminuição; a técnica os despojava da autori- 
dade no conhecimento do trabalho, tirava-Ihes a dignidade social que haviam auferido como donos de determinado saber, privava-os de remuneração condizente com a qualidade do que executavam. (PORTO ALEGRE, 1994, p. 13)

No Brasil, esse caso é ainda mais peculiar. Os projetos de inovação e industrialização do país, que trouxeram novos estudos à área de design e arquitetura, colocaram em segundo plano as tradições populares e os trabalhos manuais. Os ideais da Revolução Industrial chegaram ao Brasil com muita força, valorizando a racionalização do trabalho e tratando os objetos feitos à mão como heranças de um passado, devendo-se substituir o trabalho manual por máquinas, sinônimos, até então, de futuro e desenvolvimento (BORGES, 2011). Esse ideal vai se fortalecer por meio de algumas estratégias governamentais que visavam facilitar a entrada de empresas internacionais no país.

\begin{abstract}
Esse fenômeno ocorre através de programas de privatização das empresas públicas, do estabelecimento de novas multinacionais, das joint ventures entre empresas provenientes de diversos países, ou por meio de fusão e/ou aquisição de um grande número de empresas locais. 0 governo brasileiro, em sintonia com a política neoliberal (que se dissemina pelo mundo ocidental a partir dos anos noventa), foi amplamente benevolente (como já havia sido precedentemente nos anos sessenta, quando do estabelecimento das multinacionais) ao promover ações [...] que buscavam favorecer novos estabelecimentos de empresas globais no nosso território. (MORAES, 2006, p. 225)
\end{abstract}

Garcia e Miranda (2010) discutem como esse processo se estabeleceu na moda. As autoras sinalizam o advento, no final da década de 1940, do sistema de produção de moda conhecido como ready-to-wear (ou, em português, "pronto para vestir"), que prioriza a produção de roupa em processo de massa, visando o atendimento de demandas em uma escala global, em detrimento da confecção em ateliês de alta-costura. Essa substituição provocou uma desvalorização das técnicas artesanais, priorizando a aceleração da produção e o lucro.

Nesse novo cenário, costureiros e artesãos são colocados de lado, substituidos por profissionais com conhecimentos e habilidades técnicas preocupados essencialmente com o produto final e sua adequação às necessidades do mercado de consumo.

Visando minimizar esses aspectos negativos, a globalização tece estratégias para conquistar espaços e consumidores na contemporaneidade, desejosos por novidades constantes. Uma delas é refere-se ao trabalho feito com os diversos tipos de gostos e culturas, e a criação de objetos que sejam novos para o mercado, diferentes daqueles já oferecidos. Outro artifício diz respeito ao conceito de glocalismo, defendido como a utilização de demandas locais para a produção de bens, distanciando-se da imagem de padronização que o fenômeno da globalização denota (AVELAR, 2011).

Mesmo havendo esse desejo pela inovação e pela fabricação em escala industrial causado pelo processo de globalização, notam-se indícios que apontam para um repensar das ações de produção e consumo. Diante da emergência de novos produtos e das demandas de um mercado cada vez mais exigente, destaca-se a busca pela identidade e pelas tradições culturais, como veremos no item a seguir.

\title{
Identidade local como resistência ao mundo globalizado
}

De acordo com Avelar (2011), ao mesmo tempo que a globalização cria uma cultura homogênea por meio das comunicações digitais, distanciando-nos do domínio do Estado-nação, ela pode favorecer ideias nacionalistas, com resistência ao consumo internacionalizado e voltado para a identidade do mercado local. 
Dalpra (2009) analisa esse contexto situando o fato de que a "força homogeneizadora" do processo de globalização poderia destruir as características que são singulares a cada povo e cultura. Porém, segundo o autor, vemos, atualmente, uma modificação nesse pensamento, sendo visivel um movimento de resistência e apropriação dos bens construídos pelo saber popular, que passam a reinventar processos, sem que sejam esquecidas a cultura e os saberes regionais. Estabelece-se, dessa forma, um processo de retomada aos hábitos que outrora foram suplantados pelos ideais de desenvolvimento e buscam-se produtos dotados de caracteres regionalizados, na ânsia por driblar o sistema acelerado no qual estamos inseridos.

Mendes analisa esse fenômeno dizendo que "se as fronteiras entre o culto e 0 popular, o antigo e o novo, o local e o estrangeiro estão sendo repensadas, não é mais possivel pensar na tradição como algo que remete apenas ao passado, congelada" (MENDES, 2011, p. 78). Porto Alegre (1994) corrobora também para essa discussão e diz que as artes populares tendem a ser cristalizadas e associadas a tempos primitivos, principalmente em sociedades de classe, envolvidas em um sistema de produção de massa. Porém, essas artes não se extinguem, surgindo novas configurações para desenvolvê-las, acompanhando as transformações e as dinâmicas socioculturais.

As fronteiras culturais estão cada vez menores, possibilitando uma troca de conhecimentos antes inimaginável. Porém, é necessário conhecer o patrimônio no qual estamos inseridos, "nativizando-se".

Por um lado, quanto mais se internacionalizam as culturas, mais nos damos conta das diferenças que nos separam dos demais povos. Por outro lado, na medida em que esses obstáculos são superados, estabelece-se uma nova cultura. É um processo longo, que não se realiza instantaneamente. Trata-se da necessidade de "nativizar-se", de compreender a cultura local e fazer parte dela, mesmo que muitas diferenças ainda persistam. (AVELAR, 2011, p. 95)

0 que se pensava sobre o desaparecimento de modos produtivos pré-industriais não foi concretizado. Pelo contrário, nota-se uma tendência à expansão do lugar que o artesanato ocupa no nosso meio social, dando atenção especial à sua simbologia. "Nessa ressignificação, o que passa a contar é a capacidade dos objetos de aportar ao usuário valores que vêm sendo mais reconhecidos recentemente, como calor humano, singularidade e pertencimento" (BORGES, 2011, p. 203).

De acordo com o estilista Walter Rodrigues², a globalização gera produtos sem alma, uniformes, baseados simplesmente por seu preço acessivel e pelos concorrentes de mercado. Já os produtos com aspectos regionais são dotados de identidade e conexões com os locais onde foram criados, que lhes conferem elementos que são cada vez mais valorizados no mercado por suas características singulares.

Analisando o processo de concepção de marcas, Carvalhal (2014) aborda a importância de elas trazerem para si o DNA do seu local de origem. "Quando uma marca tem uma relação forte com o lugar onde nasceu, caracteristicas daquele lugar podem vir expressas em seus produtos, auxiliando na construção de uma assinatura" (CARVALHAL, 2014, p. 124).

Caldas (2006) corrobora com essa discussão tratando da importância que se deve dar à cultura local, utilizando-a como fonte de inspiração para o desenvolvimento de produtos. Na moda, por exemplo, essa pesquisa de vocações regionais pode ser encarada como um símbolo de distinção do produto, o que propicia uma vantagem competitiva no mercado.

No âmbito do design não é diferente. Buscam-se inspirações em temáticas ligadas a conhecimentos populares, que tratem de uma identidade, na busca do desenvolvimento de um produto que promova uma forte ligação com o consumidor.

É cada vez mais crescente, em todo mundo, o apelo por novas expressões, por soluções inovadoras que tragam uma maior vitalidade à produção 
artesanal. Aspira-se por um design de forte identidade, que já parece possivel, pois a consciência de sua importância já existe entre nós, seja por parte dos órgãos do governo, seja por outras entidades, ou entre os empresários. Partir de referências locais, do conhecimento da própria cultura, que passa por uma percepção da tradição e atingir o global, é, sem dúvida, um interessante ponto de partida. (FRANÇA, 2005, p. 11)

Cria-se, nesse novo contexto, um novo perfil do profissional de design, que volta sua preocupação para os seguintes aspectos: utilização de recursos renováveis; não acumulação de mais resíduos no ecossistema; direcionamento para a concepção de produtos com recursos provenientes de comunidades locais; união entre a produção com apoio social; e a consciência coletiva da extração e utilização eficaz dos recursos (RECH; SOUZA, 2014).

Fletcher e Grose (2011) apontam para as práticas que estão transformando o design de moda. Para as autoras, existe na atualidade uma mudança na atividade do design. Antes, essa era vista apenas sob o ponto de vista da comercialização do objeto. No entanto, um número cada vez mais crescente de pessoas questiona-se sobre seus efeitos para o meio ambiente.

De fato, o design está hoje em um ponto de "inflexão": forças econômicas, ecológicas e socioculturais maiores obrigam à reanálise dos sistemas de valor predominantes no design e dos lugares em que as habilidades de design são tradicionalmente aplicadas. Como resultado dessa reflexão, os designers começam a explorar seu potencial para transformar as coisas de maneira talvez imprevista. (FLETCHER; GROSE, 2011, p. 155)

0 profissional torna-se mais consciente do seu entorno e dos produtos que criará para oferecer ao mercado, preocupado com suas origens e seu processo de produção, utilização e descarte. "Essa nova maneira de trabalhar torna os designers muito mais envolvidos com a cultura e a sociedade e suas instituições, e, no longo prazo, pode criar oportunidades para que eles liderem mudanças sistêmicas" (FLETCHER; GROSE, 2011, p. 156).

As autoras destacam quatro papéis importantes para o designer contemporâneo, a saber: comunicador, fornecendo informações ecológicas importantes para os consumidores; facilitador, atuando não só para o fornecimento de objetos, mas enfatizando os processos e o esforço de forma colaborativa, vendo o consumidor como ator ativo no processo produtivo; ativista, fomentando discussões políticas e mudanças de pensamento na prática do consumo; e empreendedor, criando novos modelos de negócio, para um nicho de mercado mais consciente e sustentável.

Como criador de novos objetos de desejo, esse novo profissional deve apropriar-se dos signos e das demandas da atualidade sem deixar de lado o patrimônio histórico e cultural do território no qual está inserido. É esse trabalho que vai tornar o produto dotado de características únicas e com grande potencial de concorrência em meio à oferta de bens massificada.

0 design, atividade responsável pela criação, inovação e invenção de artefatos que irão compor a cultura material de determinado local, deve avaliar em seu processo de desenvolvimento os símbolos, informações e comportamentos da cultura no qual o produto estará inserido. [...] mediante os efeitos da globalização, onde a qualidade não é mais um diferencial dos produtos e serviços, mais um aspecto inseparável, a inovação pode estar no apelo original, na emoção 
e nos sentimentos que se desperta nos consumidores através de signos e símbolos de sua cultura, aproximando-o do objeto em questão. Portanto, é de suma importância que ao projetar novos produtos se tenha um entendimento acerca dos elementos que formam a cultura e a identidade do local no qual este produto será inserido. (PICHLER; MELLO, 2014, p. 1)

0 designer deve, assim, estar atento às novas tecnologias e informações, mas com os olhos voltados para a sua realidade local, para os consumidores diretos dos seus produtos e serviços, tendo em vista que esses clientes estão também em constante mutação, demandando novas atitudes e novos posicionamentos, como veremos no item seguinte.

\title{
Consumo consciente e a revalorização de saberes locais na produção e no consumo de moda
}

Em paralelo ao que foi exposto anteriormente, destaca-se um crescimento de consumidores que buscam produtos novos, mas com referências ao patrimônio local e às práticas sustentáveis, que não agridam o meio ambiente e que respeitem as pessoas envolvidas no processo produtivo.

Lipovetsky (2007) trata desse novo sujeito abordando a transição de um consumidor que vivia sob a égide do capitalismo, comprando sob influência da publicidade e do marketing de massa, para o indivíduo que busca relações mais autênticas e íntimas no seu ato de escolha, compra e utilização do objeto. Esse consumidor, cada vez mais informado sobre o processo de produção, passa a ser mais reflexivo.

\begin{abstract}
0 hiperconsumidor não está mais apenas ávido de bem-estar material, ele aparece como um solicitante exponencial de conforto psíquico, de harmonia interior e de desabrochamento subjetivo, demonstrados pelo florescimento das técnicas derivadas do desenvolvimento pessoal bem como pelo sucesso das sabedorias orientais, das novas espiritualidades, dos guias da felicidade e da sabedoria. (LIPOVETSKY, 2007, p. 15)
\end{abstract}

Sabendo do caráter finito dos recursos naturais, o novo consumidor passa a adotar práticas conscientes, equilibrando suas necessidades individuais, o uso dos recursos naturais e as demandas sociais na prática de compra, uso e descarte dos objetos (AKATU, 2005). Esse debate tem origem em um processo de reflexão sobre as consequências da produção em escala globalizada e seus efeitos sobre o consumo, cada vez mais desenfreado, e o meio ambiente.

A partir dos anos 1990, as questões relativas à sustentabilidade ambiental passaram a ser consideradas de grande importância para 0 planeta, fazendo com que a reflexão sobre o tema fosse disseminada por meio de diferentes âmbitos do conhecimento, com interesses e enfoques distintos. A abordagem atual sobre a tríade produção, consumo e meio ambiente se intensifica de maneira significativa quando passamos a considerar a relação entre a evolução tecnológica (em rápida disseminação), as matérias-primas (de livre circulação) e o fenômeno da globalização (entende-se 0 aumento produtivo e mercadológico em diferentes partes do planeta). (MORAES, 2010, p. 56)

0 consumidor passa a refletir sobre o seu processo de aquisição de bens e serviços, tendo consciência dos impactos positivos e negativos de suas escolhas, definindo, também, o que vai comprar, de quem irá obter o produto e como serão seu uso e seu descarte. Outra característica desse novo consumidor é que ele busca divulgar ações conscientes, o que promove uma rede de indivíduos mais responsáveis no que diz respeito à sua interação com o mercado (TÓDERO, 2009). 
Mezabarba \&t Goidanich (2014) trazem para a discussão dois padrões de consumo de moda da atualidade, a saber: fast fashion, movido pela rapidez, por novas possibilidades e tendências de moda, com preços acessiveis, tendo uma relação de uso e descarte frequentes e constantes, ou seja, um ciclo de vida curto; e o slow fashion, sendo o contrário do anterior, promovendo uma maior durabilidade do produto, voltado para valores sociais, culturais, ambientais e éticos.

Nessa contratendência, une-se o que Morace (2012) denomina de consumidores atores, aqueles que buscam marcas que valorizem produtos feitos em escala local e que tragam em si valores mais humanizados, diferentes da lógica capitalista de produção.

Lipovetsky corrobora com essa discussão, tratando do hiperconsumidor que busca prazeres emocionais no ato da compra, obtendo não só mercadorias, mas também experiências sensoriais, estéticas e afetivas. "A verdade é que, quanto mais se afirma o imperativo de celeridade, mais se exprimem as considerações éticas, as posturas críticas em relação às marcas e ao consumo 'irresponsável'" (LIPOVETSKY, 2007, p. 114).

Sabe-se que uma das estratégias para um comércio sustentável é o trabalho com comunidades e grupos de artesãos, contribuindo para o consumo de matérias-primas locais e, dessa forma, potencializando esses indivíduos. "Fazer com que as prioridades locais sejam relevantes para o setor da moda, para promover a sustentabilidade, é um processo potencialmente transformador, que visa fomentar a solidez econômica e, ao mesmo tempo, a diversidade cultural e estética" (FLETCHER; GROSE, 2011, p. 108).

Lee (2009) colabora com o tema, relatando o crescimento de consumidores de moda eco fashion, que respeita o meio ambiente e, sobretudo, os envolvidos no processo produtivo. Segundo a autora, essa ascensão pode ser considerada um movimento no qual entram em cena as grandes empresas, a mídia, os consumidores e as universidades, que passam a fomentar a discussão, incorporando disciplinas relacionadas à produção sustentável em seus currículos.

\section{Consumidores conscientes e sua relação com a produção localizada}

Além desse respeito ao meio no qual o bem é produzido, devem-se levar em consideração outras estratégias para o atendimento das novas demandas de consumo. Kotler, Kartajaya e Setiawan (2010) chamam nossa atenção para o fato de que 0 consumidor hoje é parte integrante da empresa, devendo essa estabelecer missões que estejam de acordo com o que o mercado está disposto a adquirir. As marcas devem prezar por sua história e por seus valores, fazendo com que os consumidores se identifiquem com ela e queiram comprar seus produtos.

0 sucesso das marcas reside na capacidade de criar mundos possíveis que têm sentido (significado) para as pessoas. Esses mundos ajudam as pessoas a alimentar a sua identidade, a pensar nesse universo e a dar sentido à sua experiência individual. Não só vender um produto, mas, sobretudo, um modo de vida, um imaginário, valores capazes de criar identificação e desencadear uma relação afetiva com a marca, aquele desejo de fazer parte. (CARVALHAL, 2014, p. 15)

Para Moraes (2010), os consumidores são partícipes ativos no processo negativo de uso e desgaste dos produtos, que gera impacto ambiental. Sabendo disso, deve-se trabalhar para a promoção do consumo consciente. Segundo Borges (2011), essa mudança de pensamento no que diz respeito à aquisição de bens de consumo está relacionada também às capacidades simbólicas do objeto, seu significado cultural e as motivações que levam à sua produção, em detrimento da sua forma e sua função básicas.

Do consumo ostentatório, registrado nas fases I e II do consumo descritas por Lipovetsky (2007), passa-se para um consumo experiencial, ligado à qualidade de vida, às motivações pessoais e ideologias do consumidor. 
Em profundidade, o consumo emocional aparece como forma dominante quando 0 ato de compra, deixando de ser comandado pela preocupação conformista com o outro, passa para um lógica desinstitucionalizada e intimizada, centrada na busca de sensações e do maior bem-estar subjetivo. A fase III significa a nova relação emocional dos indivíduos com as mercadorias, instituindo o primado do que se sente, a mudança da significação social e individual do universo consumidor que acompanha o impulso de individualização das nossas sociedades. (LIPOVETSKY, 2007, p. 46)

Carvalhal (2014) trata dos atributos que os produtos devem ter hoje para satistazer essa clientela mais crítica e seletiva. Um deles é a recompensa de autoexpressão proporcionada pelo objeto, fazendo com o que o consumidor se identifique e se expresse por meio do produto adquirido. Essa recompensa também deve ser obtida pela funcionalidade real do objeto e os valores emocionais que envolvem a sua aquisição. Outro aspecto importante ressaltado pelo autor é sobre o preço desses produtos. Os consumidores conscientes prezam pelo preço justo cobrado, corroborando para que haja uma ligação entre o produtor, que utiliza material ecologicamente correto, e 0 comércio justo e sustentável.

0 turboconsumidor, como denominado por Lipovetsky (2007), e surgido na fase III do consumo, interessa-se em saber mais sobre o produto e as consequências de seu ato de compra, tornando esta uma ação reflexiva e especulativa. "Através da rejeição e das escolhas conscientes, o consumidor experimenta uma maneira de ser sujeito, cuja autonomia se concretiza na prudência, no discernimento, na capacidade de mudar e de questionar o existente" (LIPOVETSKY, 2007, p. 139).

Estudando o caso específico de bens artesanais, Silva (2011) faz uma análise dos aspectos mercadológicos que estão envolvidos na sua produção e colabora dizendo que "o artesanato faz parte exatamente do rol de mercadorias que têm como característica privilegiada ser menos objetos utilizáveis do que bens estéticos e simbólicos" (SILVA, 2011, p. 53).

A autora ainda contribui dizendo que é exatamente o valor agregado dos objetos artesanais que chama a atenção dos consumidores, fazendo com que esses utensilios se aproximem da área do design, tendo em vista que essa disciplina envolve procedimentos técnicos e metodológicos para o desenvolvimento de produtos para o mercado.

0 artesanato é elemento ativo nesse novo cenário. Além de seu respeito às tradições culturais locais, o bem artesanal está, para Fletcher e Grose (2011), imbuído de conexões viscerais, carregando símbolos relacionados ao fato de fazer algo em vez de simplesmente adquirir, como acontece no sistema econômico vigente. De acordo com as autoras, a produção de bens feitos com técnicas artesanais pode ser considerado um ato de ativismo político, na medida em que pode influenciar nos hábitos de consumo, expressando valores ligados à sua produção.

Estabelece-se, assim, um paradoxo em nossas formas de produção na busca pelo novo, porém com identidade, com heranças culturais e que respeite o meio ambiente. Diniz (2012) trata esse fenômeno destacando que itens que prezam pelo respeito ao meio ambiente são preferidos pelos consumidores atuais e que dispõem de capital para adquirir produtos com valores agregados.

Outra característica desse processo é a revalorização de tradições culturais de determinados locais específicos. Regiões que estavam à margem da produção, retomam seu lugar como centros de difusão e criação, servindo como guias para a definição de tendências, como assinala Dalpra (2009):

Caracteristicas típicas, combinações específicas, singularidades, identidade. Seja no campo da moda, do design ou da arquitetura, seja nas manifestações artísticas ou na gastronomia, contrariando o que se cogitou ser uma tendência da nossa época a homogeneização das culturas diante da globalização, observa-se uma valorização cada vez 
maior dos elementos e "talentos" que compõem o "DNA" das diferentes sociedades e culturas. (DALPRA, 2009, p. 9)

A moda acompanha esse movimento e estabelece novos padrões estéticos para o consumo de vestuário. Volta-se, dessa forma, a produzir roupas com referências à cultura e ao artesanato brasileiro. Os grandes birôs de estilo, difusores de novas tendências e de comportamento, apropriam-se desse contexto e massificam a ideia de uma moda com olhares para o regional, para a identidade brasileira.

\footnotetext{
Após algum abandono e esquecimento do artesanato, percebe-se atualmente uma tendência de revivalismo acompanhada por um esforço de valorização e protecionismo para com esta arte secular. Com a alteração dos gostos e dos perfis de consumo, o desafio de sobrevivência do artesanato têxtil passa por incluir elementos de design. (FERREIRA; NEVES; RODRIGUES, 2012, p. 32)
}

Como exemplo disso, temos a região nordestina, que vem se tornando alvo de pesquisadores, produtores e consumidores. Dalpra (2009) explica que o Nordeste brasileiro é a escolha de diversos estrangeiros que vêm em busca de uma cultura autêntica e sincrética. Seu artesanato, carregado de informações e heranças culturais, servem como guias para a produção de peças que aliam tradição e design.

Revistas e sites especializados em tendências de moda e comportamento passam a ver em locais como o Nordeste brasileiro uma fonte de novas possibilidades, tratando-se de materiais, formas, combinações etc. Dalpra (2009) destaca que a atenção por parte das empresas para a região também está associada ao crescimento econômico registrado nos últimos anos. Os moradores tornam-se potenciais compradores, transformando o terreno propício para aplicação de novas técnicas de marketing, comunicação e vendas.

\section{A ressignificação do artesanato cearense no reality project A hora do Brasil}

Artesanato e design, diante do que foi exposto, são termos fortemente valorizados na sociedade atual, na qual se preservam as relações intimistas e as formas de consumo mais conscientes, ligadas às emoções e aos comportamentos particulares dos consumidores.

Porém, no estado do Ceará, vemos uma desvalorização dos objetos produzidos artesanalmente. Muitos deles estão perdendo suas caracteristicas essenciais em prol de uma produção mais barata e que atenda às necessidades do mercado, sem uma análise do que está por trás do objeto (artesão, técnica, saberes populares, patrimônio cultural etc.).

Borges (2011) aponta algumas alternativas para que o artesanato seja revitalizado, gerando renda para os grupos produtivos e desenvolvendo artigos competitivos no mercado. A primeira delas diz respeito às melhorias nos aspectos técnicos, desde 0 projeto e o desenvolvimento até o acabamento, que precisam passar por um processo de inspeção de qualidade.

A segunda alternativa apontada pela autora é a utilização dos bens disponiveis na região onde o produto é desenvolvido. Deve-se despertar para as riquezas naturais do local e as possibilidades de trabalho que esses materiais oferecem. Depois, necessita-se prezar pela identidade do local, focando no patrimônio e nas simbologias que o objeto fornece para quem o faz e para quem vai comprá-lo.

Após essas etapas mais técnicas, deve-se pensar na construção das marcas, com o intuito de promovê-las e provocar desejo no consumidor. Por último, a autora destaca que é indispensável que artesãos e designers pensem em ações combinadas, que 
vão de requisitos técnicos, passando pela otimização de processos e a intermediação das relações entre 0 artesanato e as necessidades do mercado.

Fletcher e Grose (2011) destacam a importância do design colaborativo, guiado por uma lógica econômica alternativa que valoriza o trabalho realizado em conjunto e vê os participantes como atores ativos no processo de execução e consumo do bem, compartilhando as atividades e os benefícios advindos delas.

No design colaborativo, o próprio processo de design é transformado. Aqui, a preocupação é não tanto produzir objetos refinados, mas sim desenvolver habilidades na população de usuários. Enfatizam-se a compreensão, o projeto e a ação coletivos - e esse conhecimento e essa experiência em expansão não são reservados ao designer amador, mas influenciam também o designer profissional. (FLECTHER; GROSE, 2011, p. 145)

Pensando nas condições supracitadas, e para dar mais substância ao que vem sendo exposto até agora, escolheu-se, como objeto de estudo, o reality project, uma ação promovida pelo Senac/CE durante um dos maiores eventos de moda autoral do pais, o Dragão Fashion Brasil, no ano de 2012. 0 evento é conhecido por reunir estilistas com marcas próprias, com forte apelo conceitual e autoral, destacando-se por dar visibilidade aos trabalhos que valorizam a identidade e 0 artesanato local.

0 projeto envolveu designers, estudantes, costureiras, modelistas e artesãos com o intuito de confeccionar uma coleção de moda, com direção criativa do estilista e designer Jum Nakao, conhecido internacionalmente por seus trabalhos, notadamente por seu desfile $A$ costura do invisível, apresentado na São Paulo Fashion Week, em 2004.

Para a realização desse projeto, um edital intitulado $A$ redescoberta do paraíso brasileiro foi lançado, chamando profissionais e estudantes empenhados em repensar a moda produzida no Brasil e os materiais utilizados nesse processo. Assim, mais de 20 atores foram selecionados para realizar a coleção que seria confeccionada durante uma semana, nos moldes de um reality show, filmado e transmitido via internet. Os participantes selecionados para compor a equipe de trabalho podem ser visualizados na imagem 1.

Imagem 1: Equipe de trabalho3.

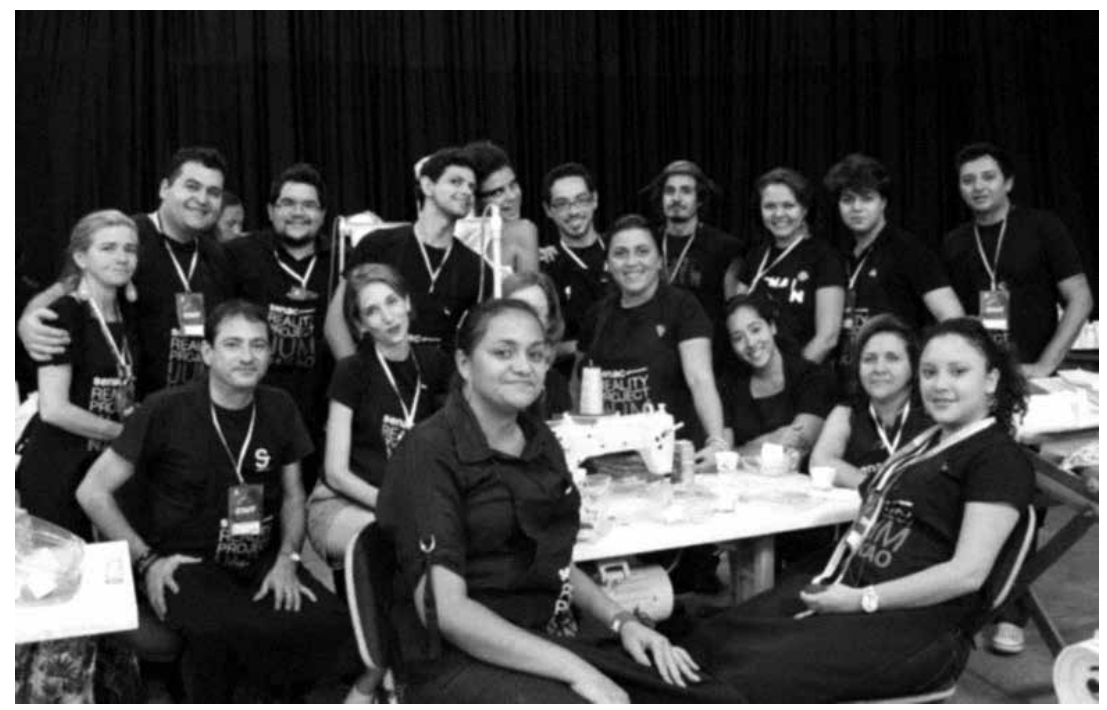

Fonte: <www.dfhouse.com.br>. Acesso em: 20 ago. 2014.

Objetivava-se, com esse projeto, mostrar um Nordeste como forte centro de produção de moda no Brasil, tendo em vista o caráter de inovação e a riqueza dos elementos de artesanato da região. Assim, uma mini-indústria foi montada para a execução 
das peças, com paredes transparentes para que todos os visitantes pudessem acompanhar o processo de produção.

Após uma semana de trabalho, e envolvendo os saberes de todos os sujeitos envolvidos, foi apresentado o desfile e intitulado $A$ hora do Brasil, no qual se puderam ver elementos da cultura nordestina nas roupas, na trilha sonora e na cenografia montada para a apresentação. A ópera 0 guarani foi revisitada, ganhando outros ritmos, acompanhada de sons de pífano. Na passarela, foi montado um pequeno labirinto, no qual as modelos cruzavam caminhos bloqueados por grandes murais de xilogravura.

Alguns elementos das diversas tipologias do artesanato cearense foram elencados. Optou-se por um trabalho sobre o couro, as cestarias, as rendas e, como citado anteriormente, a xilogravura. Porém, esses elementos foram repensados para que fosse criada uma imagem de moda com forte impacto, ressignificando os materiais e os processos originais utilizados na confecção do artesanato, como pode ser visto na imagem abaixo.

Imagem 2: Registros do backstage e da passarela do desfile.
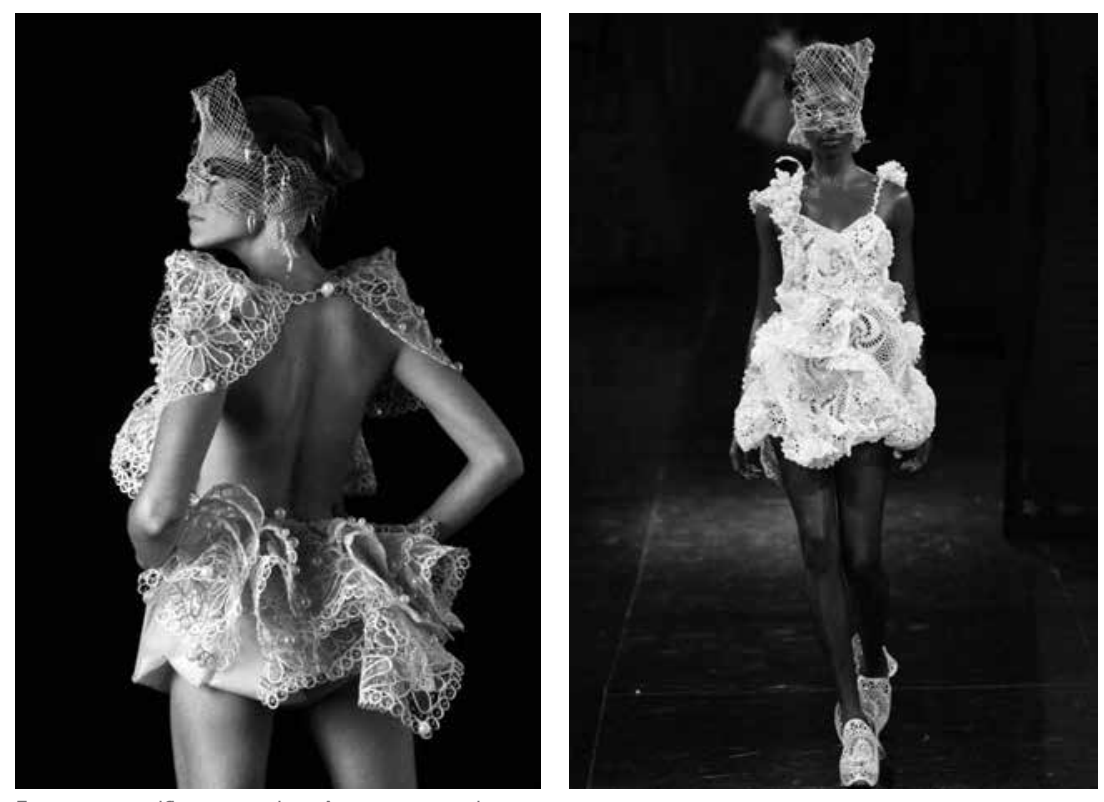

Fez-se, para a construção deste trabalho, uma análise documental do produto desenvolvido durante o project $A$ hora do Brasil, notadamente do catálogo, do minidocumentário e de matérias sobre a realização desse projeto em sites especializados em moda e design.

A análise documental é um dos métodos utilizados para a execução de pesquisas. Para a sua realização, lança-se mão de diversos tipos de documentos, tais como fotografias, jornais e revistas, que possam ser úteis para o esclarecimento das questões que se desejam elucidar. A pesquisa documental difere da pesquisa bibliográfica pelo fato de que esta apresenta dados secundários, já tratados cientificamente. A primeira apresenta o objeto de forma bruta (primária), sendo o pesquisador responsável por sua elucidação e problematização (SÁ-SILVA; ALMEIDA; GUINDANI, 2009).

Analisando, primeiramente, o catálogo feito com fotos do processo de produção e do desfile do reality project, conseguiu-se ter uma dimensão do trabalho de ressignificação do artesanato proposto no projeto. A começar pela capa, um misto de estampa digital com detalhes em couro natural recortados a laser, remetendo aos elementos mostrados na passarela. 
Um pequeno livro de literatura de cordel, disponibilizado com catálogo, apresenta como foi a dinâmica do evento, com ilustrações em xilogravura, as mesmas utilizadas nos murais confeccionados como elementos de cena para o desfile.

\begin{abstract}
E A hora do Brasil o nome da coleção que, com traços nordestinos, fez a sua criação, aproveitando o momento que vive nossa nação. Os artefatos mais rústicos, com seus traços naturais, as fibras de buriti, o couro dos animais, com materiais mais nobres: seda, pérolas e cristais. Revelaram a inteligência que no Brasil predomina, unindo o rústico e o luxo numa coleção divina, mostrando a força que tem nossa raiz nordestina. (PAIXÃO, 2013)
\end{abstract}

Os versos da poesia de Fernando Paixão apresentam-nos um elemento muito importante da cultura popular nordestina: a literatura de cordel. Aqui, ela vem reafirmar o caráter de revalorização do patrimônio cultural, abordando um tema do cotidiano e dando ritmo para que o leitor seja transportado para o universo criado no dia do desfile. "0 Nordeste é o Brasil que o mundo ainda não conhece". Esta frase, contida no catálogo, demonstra a intenção da imagem criada no desfile e da ressignificação dos materiais, chamando atenção para uma região rica em elementos estéticos e culturais.

Identificou-se uma clara intenção do catálogo de colocar em evidência os materiais e as técnicas utilizadas durante a confecção das peças do desfile. 0 material nos fornece imagens de elementos sendo costurados e bordados à mão. Materiais como couro, fibra de buriti e peças em crochê ganham ares nobres com bordados de pérolas e cristais, recortes a lasere trançados inusitados. Outras técnicas são colocadas em evidência, como o macramê e o trabalho realizado sobre moulage, típica técnica de alta-costura.

As duas imagens abaixo podem exemplificar o trabalho de composição entre elementos do artesanato nordestino e materiais mais finos. A primeira traz uma parte superior confeccionada em fibra de buriti e ornamentada com bordados de pérola. 0 short, com modelagem mais bufante, é de seda. Já o segundo look é composto por uma saia com modelagem mais próxima ao corpo, com trabalho de sobreposição de trançado sobre o linho. 0 top de couro tem recortes que lembram uma renda, ganhando formas mais modernas e estruturadas.

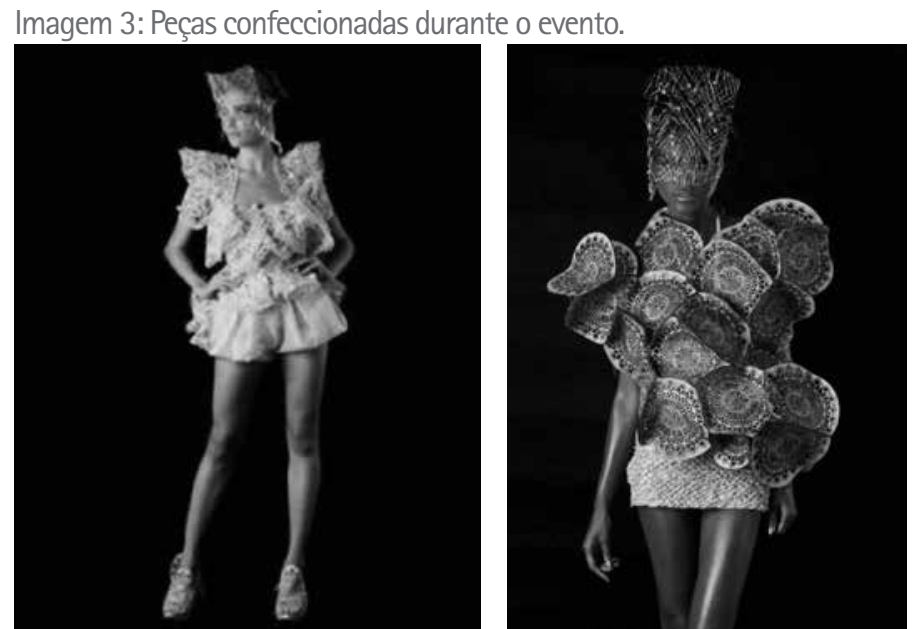

Fonte: Nakao (2013) 
Os dois looks atestam a ação inovadora de unir elementos tradicionais com materiais e técnicas diferenciados. 0 rústico remete à força e à bravura da muIher nordestina. 0 fino traz a feminilidade dessa persona, tratada de maneira luxuosa e contemporânea.

Para dar mais suporte a essa etapa da pesquisa, foi analisado o minidocumentário distribuído junto com o catálogo, bem como outros vídeos disponíveis na internet. Com pouco mais de 20 minutos, mostra todo o processo de desenvolvimento da coleção, desde as primeiras reuniões, nas quais o estilista Jum Nakao apresentou o projeto aos participantes, deu as instruções básicas sobre 0 andamento do reality e falou sobre suas ideias para o desfile, como pode ser visto no seguinte trecho retirado do vídeo:

Nós temos que pensar da seguinte forma: um desfile, ele dura sete minutos. Sete minutos é muito concentrado, aonde as pessoas se sentam, cada uma chega lá com seus problemas, cansadas, com calor com frio, enfim [...] e ele tem que entrar na sua história. Ele tem que se encantar e acreditar que aquele sonho vale a pena ser vivido. [...] o que funciona é o impacto. A pessoa tem que estar lá e sentir "isso é tão potente que me tirou a respiração". A gente tem que fazer com que as pessoas sobrevivam sete minutos sem respirar. Isso é um desfile. (NAKA0, 2013)

0 vídeo, registrou todos os dias do evento, apontando as metodologias empregadas em cada etapa do desenvolvimento da coleção. No primeiro dia, deu-se o processo de reconhecimento do local e das matérias que seriam usadas, em um trabalho que o diretor criativo chamou de "desconstruir para construir", experimentando as possibilidades que elas forneciam para os participantes.

No dia seguinte, foi iniciada a fase do modelar, durante a qual os experimentos feitos no dia anterior foram colocados em prática na busca de novas formas. 0 terceiro dia foi reservado para a execução das peças, prova da maquiagem e concepção de cenografia, ajustando-se as silhuetas e os acessórios para a composição dos looks. No dia seguinte, os trabalhos passaram para a fase de conclusão, preparando tudo para 0 quinto dia, no qual tudo deveria ser apresentado em forma de desfile.

Analisando as falas tanto do diretor criativo como dos participantes, pôde-se verificar o caráter coletivo do reality. Todos citam a experiência como inovadora, na qual cada um pôde contribuir com o seu conhecimento na construção de um produto único e cheio de referências à cultura local.

É possível notar, nesse vídeo, uma ajuda mútua e constante de todos os atores. A todo instante, são vistos trabalhos realizados em dupla ou trio, $e_{1}$ nessas equipes de trabalho, não se encontra a figura de um líder, mas sim de pessoas dotadas de saberes distintos trabalhando em prol de um objetivo comum, cada uma contribuindo com sua especialidade.

0 resultado disso foi mostrado em um desfile de 14 minutos, iniciado ao som da ópera O guarani, de Carlos Gomes, clássico tema de $A$ voz do Brasil, programa transmitido diariamente nas rádios nacionais. Retomando o trabalho de união entre o clássico e o rústico, elementos da música popular nordestina compõem a trilha sonora, notadamente 0 som da rabeca e do pífano. Essa miscelânea de ritmos dá o tom aos passos das modelos, que encenam ora guerreiras dotadas de máscaras e armaduras de couro, ora princesas com cristais, pérolas e sedas.

Outro video analisado foi o do site Take the Trend. Este mostra tanto os momentos que antecederam o desfile como os detalhes da passarela. Tudo é tratado, neste último, dando ênfase aos materiais, acessórios e acabamentos. 
Imagem 4: Detalhes da maquiagem e acessório de cabeça.
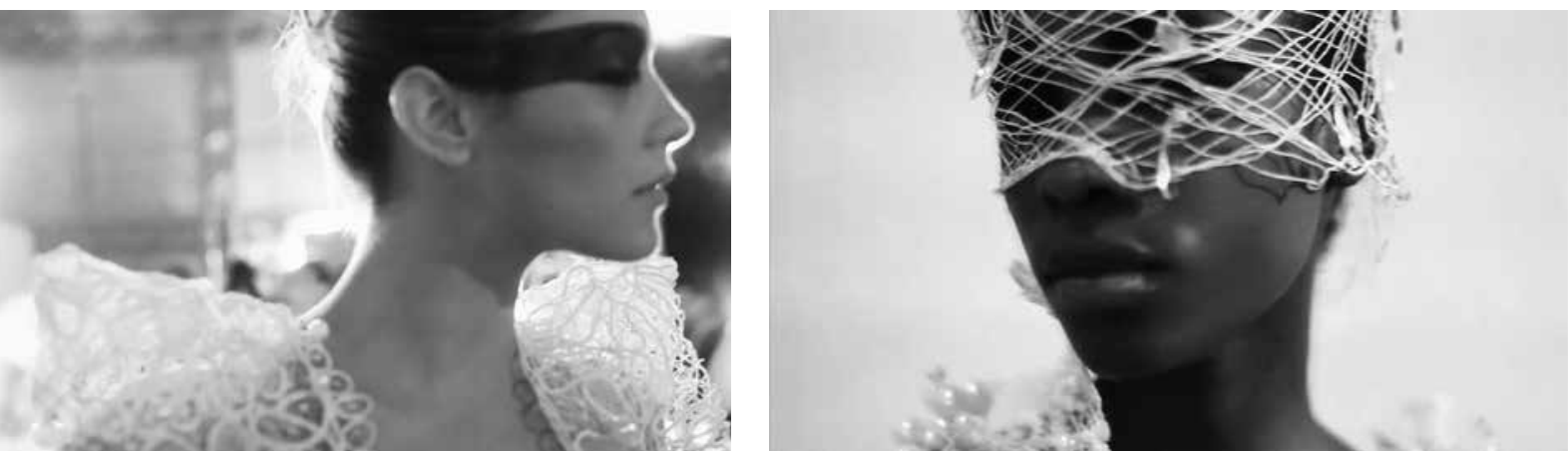

Fonte: <takethetrend.com.br ${ }^{4}$. Acesso em: 10 mar. 2015

A filmagem prioriza a tomada dos elementos em zoom, como pode ser visto nas imagens acima, favorecendo uma melhor percepção das texturas e dos bordados pelo espectador. A trilha sonora desse vídeo também mescla os elementos clássicos com o som rústico nordestino, corroborando para a estética apresentada no desfile. As modelos seguem esse arquétipo, estando delicadas e singelas no primeiro momento e fortes e destemidas no segundo.

Analisando, por fim, matérias divulgadas em sites e revistas ${ }^{5}$ especializadas, fica [102] claro o êxito da coleção no seu trabalho de ressignificação do artesanato nordestino, bem como também seu carácter inovador, por reunir estudantes, profissionais e artesãos em um só espaço para a construção de um só produto.

Chama a atenção o fato de todos mencionarem o trabalho de forma colaborativa, não se estabelecendo autoria a nenhum look especificamente. Mesmo o estilista Jum Nakao, sendo um profissional renomado, apontado como idealizador e curador do projeto, não recebeu autoria pelos looks confeccionados durante o reality.

\section{Imagem 5: Editorial Ceará autoral.}
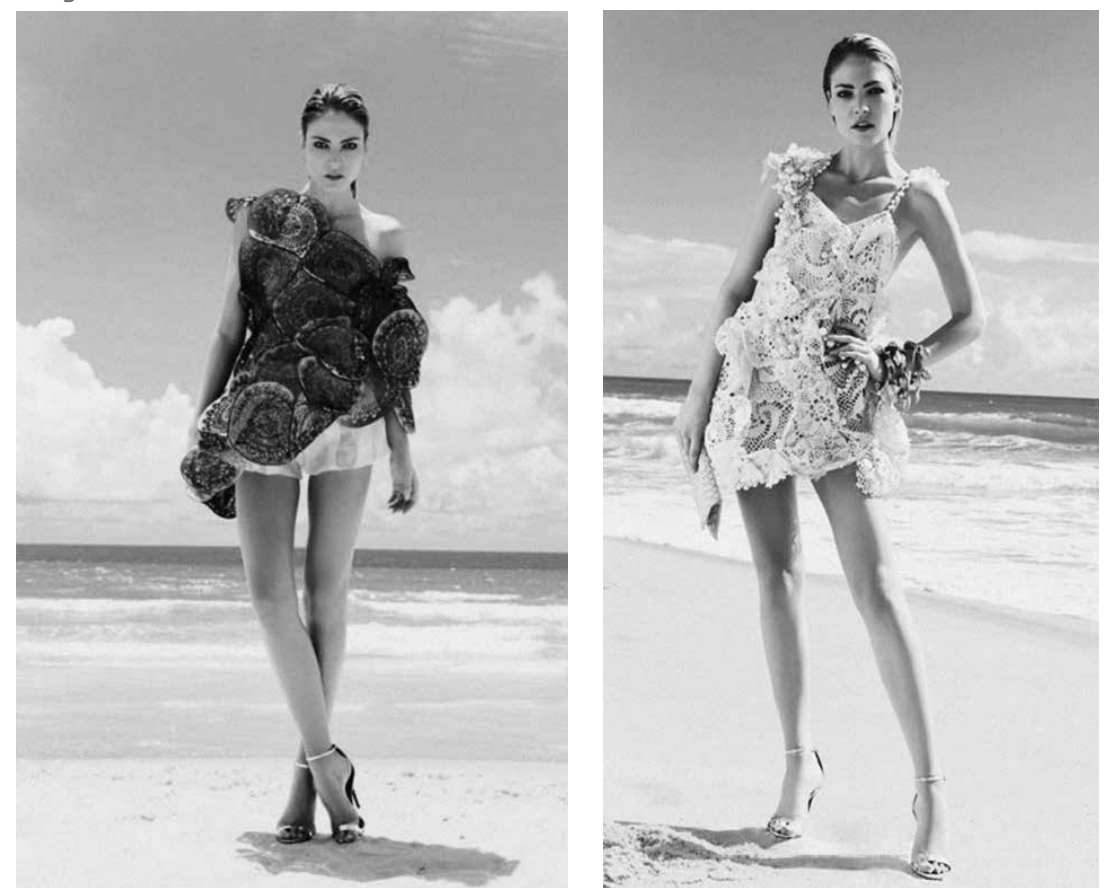

Fonte: Vogue Brasil (2013). 
As imagens acima, retiradas do editorial de moda realizado pela revista Vogue Brasil para sua edição de junho de 2013, atestam ainda o apuro estético e o caráter luxuoso das peças confeccionadas durante o reality.

Reconfigurados, com novos elementos de styling feitos por outras marcas locais, os looks demonstram o potencial criativo dos materiais utilizados, fornecendo referências de moda conceitual com elementos da cultura do estado do Ceará.

Vale ressaltar outras atividades realizadas com o produto obtido durante o reality project. Além de exposições em diversos estabelecimentos de Fortaleza, a coleção foi também apresentada, no mesmo ano, na Casa de Criadores, evento de moda que acontece na cidade de São Paulo.

Aliando tradição e respeito aos valores culturais locais e unindo a isso novos olhares em termos de moda e design, pôde-se construir um desfile com alto grau de requinte e valores simbólicos, que nos fazem repensar nossa relação com os produtos desenvolvidos em escala industrial, sem histórias e valores, e com as riquezas populares, dotadas de significado e possibilidades.

Produto final do Reality Project, a coleção A Hora do Brasil foi apresentada ao público em um desfile apotetótico, no encerramento do DFB 2012. Em 22 looks, uma plateia deslumbrada via passar, uma a uma, peças cujo grau de sofisticação tornava impossivel lembrar que foram desenvolvidas em tão pouco tempo. (TRAVESSONI, 2013 p. 111)

A matéria ressignificada ganha status de luxo. Bens antes esquecidos voltam à cena para mostrar a cultura popular de forma contemporânea e com elementos de valor agregado.

\section{Conclusão}

Culturas populares regionais, artesanato, matéria-prima natural e sustentável, identidade da moda brasileira. Todos esses conceitos são, como pôde ser visto ao longo deste trabalho, objetos contemporâneos de análises e estudos que tentam explicar nossas raizes, transportando-as aos produtos fabricados no Brasil.

Tentando melhor compreender essas relações, voltou-se o olhar para a região Nordeste do Brasil, especificamente para o estado do Ceará, com o intuito de perceber quais são as características do seu artesanato e suas inter-relações com o design e a moda contemporâneos. Esta análise objetivou destacar os parâmetros de relação entre os temas citados, identificando estratégias para a produção e a valorização de bens com apelo cultural e regional.

Vê-se, ao contrário do que se pensava, uma tendência à expansão do lugar que o artesanato ocupa no nosso meio social, recebendo atenção especial por parte de órgãos de educação e fomento, visto que artesanato e design unem-se para o desenvolvimento de produtos contemporâneos, com características culturais próprias, mas, também, com ares novos, ancorados pelos novos desejos do mercado. Como personagens principais desse contexto temos os artesãos e designers.

Hoje, produtos que unem técnicas artesanais e elementos de design são vistos como objetos de alto valor agregado, com traços de luxo, pois têm caráter único e são feitos em pequena escala. Na produção desses bens, o artesão deposita toda a bagagem de conhecimentos adquiridos de sua familia e de sua comunidade, lançando mão da matéria-prima que sua região oferece. Muitos designers utilizam essas referências em seus trabalhos, reformulando-as e agregando mais valor às suas criações.

Surge, nesse contexto, um novo perfil do profissional de design, preocupado com o respeito pela cultura popular, a consciência de identidade coletiva, a utilização de 
recursos renováveis, o uso e o descarte de matéria-prima, a não acumulação de resíduos no ecossistema e o uso de recursos locais na concepção de produtos.

0 profissional designer apropria-se dos signos e demandas atuais, sem esquecer o patrimônio histórico e social do lugar no qual ele está inserido. É esse trabalho que vai tornar o produto dotado de características únicas e com grande potencial de concorrência em meio à oferta de bens massificada.

Com o estudo do projeto A hora do Brasil, percebeu-se que esse tipo de iniciativa pode ter consequências que ultrapassam a simples produção de novos utensílios de moda. Unindo tradição cultural e elementos de moda e design, construiu-se um desfile requintado e rico em simbologias, com respeito à cultura local, mas com perspectivas globais, aliadas às tendências mercadológicas. Essa iniciativa nos faz repensar a nossa relação com os produtos desenvolvidos em escala industrial, produzidos de forma padronizada e visando apenas ao lucro do empresariado.

\section{NOTAS}

[1] Informação obtida no workshop Sistema Moda Brasil, proferido no dia 28 de agosto de 2014, na Federação das Indústrias do Estado do Ceará (FIEC).

${ }^{[2]}$ A equipe de trabalho do reality project foi composta pelos seguintes participantes: Aline de Silva Morais, Ana Elizabeth M. Loureiro, Cláudio da Silveira Quinderé, Carla Silva Pereira, Cristina R. F. Silva, Érico Gondim, Francisco Adamastor Ferreira, Francisco das Chagas M. Soares, Helena Barbieri Tozzi, Leilane Mota Barros, Lindimarcia Ramires de Almeida, Marcelo Lima Ferreira, Maria Cristina B. Maia, Pedro Renan de Oliveira, Roberto Dias, Rodrigo Torres S. Canvalho, Sara G. B. de Almeida, Sérgio Melo, Tomas Muñoz Aguirre e Wilson Pessoa Dias Neto. ${ }^{[3]}$ Video teaser produzido pelo site Take the Trend. Disponivel em: <http://takethetrend.com/2012/04/18/realityproject-por-jum-nakao/>. Acesso em: 10 mar. 2015.

${ }^{[4]}$ Sites analisados: Desenroladas. Disponivel em: $<$ http://desenroladas.com.br/sem-categoria/o-emocionanteresultado-do-reality-project-por-jum-nakao/>, e Chic, disponível em: <http://chic.uol.com.br/moda/noticia/ feita-ao-vivo-jum-nakao-explica-projeto-que-somou-moda-e-artesanato-em-colecao-desfilada-na-casade-criadores>. Acessos em: 15 mar. 2015

\section{REFERÊNCIAS}

AKATU, Instituto. Descobrindo o consumidor consciente. 2005. Disponivel em: <http://www.akatu.org.br/ Content/Akatu/Arquivos/file/Publicacoes/24-consum.pdfs. Acesso em: 10 set. de 2014.

AVELAR, Suzana. Moda, globalização e novas tecnologias. 2. ed. São Paulo: Estação das Letras e Cores Editora, 2011.

. A cultura no mundo líquido moderno. Rio de Janeiro: Zahar, 2013.

BAUMAN, Zygmunt. Globalização:as consequências humanas. Rio de Janeiro: Jorge Zahar, 1999. 
BORGES, Adélia. Design + artesanato:o caminho brasileiro. São Paulo: Terceiro Nome, 2011.

CALDAS, Dario. Observatório de sinais:teoria e prática da pesquisa de tendências. Rio de Janeiro: Senac Rio, 2006.

CARVALHAL, André. A moda imita a vida:como construir uma marca de moda. São Paulo: Estação das Letras e Cores, 2014.

DALPRA, Patricia (Org.). DNA Brasil:tendências e conceitos emergentes para as cinco regiões brasileiras. São Paulo: Estação das Letras e Cores, 2009.

DINIZ, Cláudio. Mercado do luxo no Brasil:tendências e oportunidades. São Paulo: Seoman, 2012.

FERREIRA, Ângela Sá; NEVES, Manuela; RODRIQUES, Cristina. Design e artesanato: um projeto sustentável. Redige, v. 3, n. 1, 2012.

FLETCHER, Kate; GROSE, Lynda. Moda \&tsustentabilidade:design para mudança. São Paulo: Senac, 2011

FRANÇA, Rosa Alice. Design e artesanato: uma proposta social. In: Revista Design em foco, v. II, n. 2, Salvador, 2005

GARCIA, Carol; MIRANDA, Ana Paula. Moda é comunicação:experiências, memórias, vinculos. São Paulo: Editora Anhembi Morumbi, 2010.

KOTLER, Philip; KARTAJAYA, Hermawan; SEIIAWAN, Iwan. Marketing 3.0: as forças que estão definindo o novo marketing centrado no ser humano. Rio de Janeiro: Elsevier, 2010.

LEE, Matilda. Eco chic:o guia da moda ética para a consumidora consciente. São Paulo: Larousse do Brasil, 2009.

LIPOVETSKY, Gilles. A felicidade paradoxal:ensaio sobre a sociedade de hiperconsumo. São Paulo: Companhia das Letras, 2007.

MENDES, Francisca R. N. Modelando a vida no córrego de Areia:tradição, saberes e itinerários das louceiras. Fortaleza: Expressão Gráfica, 2011.

MEZABARBA, Solange R.; GOIDANICH, Maria Elisabeth. Fast fashion x slow fashion:consumidoras, vestuário e diferentes critérios de escolha. $10^{\circ}$ Colóquio de Moda. $7^{\circledR}$ Edição Internacional. $1^{\circ}$ Congresso Brasileiro de Iniciação Científica em Design de Moda, 2014.

MORACE, Francesco. Consumo autoral:as gerações como empresas criativas. São Paulo: Estação das Letras e Cores, 2012.

MORAES, Dijon de. Análise do design brasileiro:entre mimese e mestiçagem. São Paulo: Edgard Blucher, 2006.

Metaprojeto:o design do design. São Paulo: Edgard Blucher, 2010.

NAKAO, Jum. A hora do Brasil. Fortaleza: Senac/CE, v. 1, n. 1, 2013.

PAIXÃO, Fernando. A hora do Brasil (cordel). In.: NAKAO, Jum. A hora do Brasil. Fortaleza: Senac/CE, v. 1 , ก. 1, 2013.

PICHLER, R. F. MELLO, C. I. O Design e a valorizacão da identidade local. Disponivel em: <http://www. pgdesign.ufrgs.br/designetecnologia/index.php/det/article/viewFile/67/44>. Acesso em: 19 maio 2014.

PORTO ALEGRE, Sylvia. Mãos de mestre:itinerários da arte e da tradição. São Paulo: Maltese, 1994.

RECH, Sandra R.; SOUZA, Renata Karoline R. de. Ecoluxo e sustentabilidade:um novo comportamento do consumidor. Disponivel em: <http://www.ceart.udesc.br/revista_dapesquisa/volume4/numero1/moda/ ecoluxoesust.pdf . Acesso em: 19 maio 2014.

SÁ-SILVA, Jackson R.; ALMEIDA, Cristóvão D. de; GUINDANI, Joel F. Pesquisa documental:pistas teóricas e metodológicas. Revista brasileira de história Et ciências sociais, ano I, n. I, 2009.

SANTOS, Tania Steren. Globalização e exclusão:dialéticas da mundialização do capital. Porto Alegre: Sociologias, ano 3, n. 6, jul/dez 2001, p. 170-198.

SILVA, Emanuelle Kelly Ribeiro da. Quando a cultura entra na moda. Fortaleza: Edições UFC, 2011.

SUDJIC, Deyan. A linguagem das coisas. Rio de Janeiro: Intrínseca, 2010.

TÓDERO, Mirele. Consumo consciente e percepção do consumidor sobre ações corporativas vinculadas ao conceito de responsabilidade social:um estudo no setor da saúde. Dissertação (Mestrado). Universidade de Caxias do Sul. Disponivel em: <http:/tede.ucs.br/tde_arquivos/5/TDE-2009-11-30T151024Z-317/

Publico/Dissertacao\%20Mirele\%20Todero.pdf $>$. Acesso em: 12 set. 2014.

TRAVESSONI, Márcia (Org). Anuário da moda no Ceará 2012-2013. Fortaleza: Diário do Nordeste, 2013. Vogue Brasil. São Paulo: Globo Condé Nast, n. 418, jun. 2013. 